\title{
Determinants of GDP growth in Scandinavian countries with special reference to scientific progress
}

\author{
Adam Chlebisz, Mateusz Mierzejewski
}

\begin{abstract}
A B S T R A C T
Objective: The study is aimed at verifying the main determinants of GDP growth in Scandinavian countries with special regard to scientific progress.

Research Design \& Methods: The theoretical part presents economic growth models (Romer learning-by-doing model and McMahon endogenous growth model). In the empirical study, they were verified on the example of Scandinavian countries. For this purpose, multiple regression analysis was used. Models have been developed to explain GDP per capita (as a measure of development) using variables determining work, human and physical capital. The variables included especially determinants of education, scientific development and new technologies.
\end{abstract}

Findings: The study showed that the economic growth of Scandinavian countries is strongly associated not only with the development of factors mentioned in classical growth models (referring to scientific progress) but also the others, e.g. witch increase of medium and high-tech exports as \% of manufactured exports in Sweden and Denmark. Moreover, it was indicated that scientific progress plays a particularly important role in the economic growth in these countries.

Contribution \& Value Added: The study provides current confirmation of theoretical models of economic growth for highly developed countries, where education and human capital are very important in the context of their development. Also, key determinants constituting the economic development of these countries were indicated. Similar verification may be used in the future for medium-developed and developing countries.

\section{Article type: research paper}

Keywords: $\quad$ economic growth; scientific development; education impact; human Keywords: $\quad$ capital; scientific progress; Scandinavian countries; Nordic countries JEL codes: 0470, 0110 Article accepted: 30 September 2020

\section{Suggested citation:}

Chlebisz, A., \& Mierzejewski, M. (2020). Determinants of GDP growth in Scandinavian countries with special reference to scientific progress. International Entrepreneurship Review (previously published as International Entrepreneurship / Przedsiębiorczość Międzynarodowa), 6(3), 21-35. https://doi.org/10.15678/IER.2020.0603.02 


\section{INTRODUCTION}

Understanding the nature of economic growth and identifying its components is one of the key problems in economics. As North (2010, p. 7) states, "understanding economic growth makes it possible to improve human well-being, reduce misery and extreme poverty". Contemporary models of economic growth are focused on knowledge or science as a key determinant. On the other hand, education itself has long been seen as an extremely important indicator of economic prosperity (Hanushek \& Woessmann, 2020).

Along with the growing role of human capital in modern enterprises, research on explaining economic growth has changed significantly (Garncarz \& Mierzejewski, 2019). In the context of the study on the impact of education on economic growth, several mechanisms are indicated in the literature. One of them is to increase human capital through education, which then increases the productivity of work and thereby obtains a higher level of production balance - neoclassical theory, including Mankiw, Romer and Weil (1992). Lucas (1988), Romer (1990a), Aghion and Howitt (1998), in turn, focused on the innovative potential of the economy, the development of new technologies and products in growth research. A different approach was characterized by Nelson and Phelps (1966) as well as Benhabib and Spiegel (1994). They considered education as the dissemination and transfer of knowledge necessary to deepen information, as well as understanding, handling and implementing already developed new technologies to promote economic growth.

As indicated by a study by Sala-i-Martin, Doppelhofer and Miller (2004) on a sample of 88 countries for 1960-1996, the strongest factor influencing GDP per capita was primary education. The strong positive correlation between quantitative measures of education and economic growth has been repeatedly confirmed in studies of later studies(Chlebisz, Gruszowski \& Igielski, 2019), and the most common measure used has been the average years of education for the working-age population (Krueger \& Lindahl, 2001; Topel, 1999). As Mas, Hofman and Benages (1998) emphasize, the most often used to measure the intensity of knowledge components are research and development expenditure in the production sector, while human capital in service sectors.

Human capital is a very important determinant of economic growth (Galor \& Tsiddon, 1997). Research indicates that it is not only a transmission and embodiment of available knowledge in people, but it is primarily responsible for the creation of new knowledge, which is a source of innovation and technological changes. These in turn drive all production factors (Mincer, 1984). Scientific progress in this paper is defined as an increase of value of qualitative variables and the improvement of quantitative variables determined by science, education, innovation and research development, which then testify to the increase in human capital, which in turn translates into economic growth (Becker, 1993; Pelinescu, 2015). The effect is indicated to be visible in at least two aspects: (i) human capital influences the internal rate of innovation (Romer, 1990b); (ii) human capital influences the rate of diffusion of technology in the spirit and also an increase of $1 \%$ of the capital stock leads to a $0.13 \%$ increase in the rate of economic growth (Nelson \& Phelps, 1966). Hence, investments in education and training are extremely important for the development of a given country (Wilson \& Briscoe, 2004). In the Scandinavian countries they are at a very high level compared to other European countries (OECD, 2020). However, the literature lacks attempt which show the relationship between the variables determining 
education, innovation and scientific development and the economic growth of these countries. Based on Sweden, an attempt was made to reconcile evidence on the effect of schooling on income and GDP growth. It was then shown that the increase in the level of education is not significantly related to the economic growth of the country (Krueger \& Lindahl, 1999). In turn, studies conducted on data from Norway showed that investing in innovation has a positive effect on the Norwegian economic growth (Silfvenius, 2014). However, there is still no approach that would take into account more variables and would include Scandinavian countries in total. This study aims at verifying the main determinants of GDP growth in Scandinavian countries, with special regard to scientific progress. Therefore, the following research hypothesis was formulated: scientific progress has an essential impact on GDP growth in Scandinavian countries.

\section{LITERATURE REVIEW}

Economic growth models can be divided into two groups: neoclassical and endogenous models. neoclassical models assume the occurrence of decreasing revenues from reproducible factors of production and constant revenues from the scale. The classic model represented by Ricardo and Malthus assumes that the economy will stagnate in the long run, because with non-variable technology and natural resources, capital investments and labour inputs are subject to the law of diminishing revenues - which was justified by traditional factors of production: land, physical capital and unskilled labour (Sato, 1964). This group includes the Solow (1956), Ramsey (1928) and Diamond (1965) models. Neoclassical growth theory does not precisely explain the main determinants of long-term growth, indicating that technical progress, which is exogenous in nature, remains the main factor in this time horizon. The category of these models is widely used to explain the differences between the economic states of different countries - the Solow model indicates that the differences occurring at the level of GDP per capita income are largely explained by the savings rate, the rate of human capital accumulation and the population growth rate. It is built based on trade flows between market participants (Wang, 2019).

Endogenous models assume at least constant revenues from reproducible production factors. Their characteristic feature is the rate of return explained by the model itself (in the case of neoclassical it is adopted based on exogenous assumptions that relate to the development of important parameters, e.g. technical progress). Another element that distinguishes endogenous models is the perception of the accumulation of production factors for long-term growth. According to them, the accumulation of knowledge allows the economy to maintain a permanently higher growth dynamics, while in the light of neoclassical theories this factor is only temporary. The endogenous approach focuses on the attempt to quantify and identify the impact of determinants that shape long-term economic growth (Florczak, 2009). The basic endogenous models are Romer's learning-by-doing model (Romer, 1986), Lucas model (Lucas, 1988), Rebelo model (Rebelo, 1991), and models with the increasing number of goods and models with the improving quality of goods. The new growth theory also includes the MankiwRomer-Weil model (Mankiw et al., 1992). It is an extended version of the Solow model, which in turn presented next to capital and labour - technological progress, which was responsible for increasing productivity (Florczak, 2009). 


\section{Romer learning-by-doing model}

One of the flagship examples of models aimed at explaining contemporary economic growth is the Romer learning-by-doing model. Compared to neoclassical models, the Romer model does not assume decreasing revenues from reproducible factors of production. In this approach, knowledge is the only reproducible factor of production that shows growing revenues at the level of the entire economy. According to the author of the model, the knowledge that arises from the investments of individual enterprises can spread unlimitedly across the entire economy, and what's more, it can be used by enterprises without incurring additional costs (Romer, 1986).

The production function in the discussed model is marked by:

where:

$$
f_{i}\left(a_{i}, k_{i}, A\right)
$$

$a_{i}$ - level of knowledge of a given company;

$k_{i}$ - expenditure of other factors of production (capital, labour, etc.);

$A$ - the general level of knowledge in the economy (sum of knowledge possessed by $N$ companies).

From the assumption that knowledge is the only reproducible factor of production, it follows that $k_{i}=$ const. We also assume that all enterprises in the economy are identical, therefore:

$$
\begin{gathered}
f_{i}\left(a_{i}, k_{i}, A\right)=f(a, k, A) \\
A=N a
\end{gathered}
$$

At the level of the entire economy, which is the main aspect of this article, the function of the economy in the model is recorded as:

$$
f(a, k, A)=f(a, k, N a)=F
$$

The marginal productivity of knowledge at the level of the entire economy is increasing, while at the level of a single enterprise it is decreasing or permanent, therefore:

$$
\frac{d^{2} f(a, A)}{d a^{2}} \leq 0 ; \quad \frac{d^{2} F(a,)}{d a^{2}}>0
$$

Production in the model can be allocated in two ways: consumption (c) or for investments $(i)$, which create new knowledge: $f=c+i$. The accumulation of knowledge takes place according to the function $g(i / a)$, showing decreasing revenues and the constrained constant $\gamma$ :

$$
\frac{\dot{a}}{a}=g\left(\frac{i}{a}\right)<\gamma
$$

The restriction introduced was set so that consumption and utility would not grow indefinitely. The utility function in the model has the form:

where:

$$
U=\int_{0}^{\infty} u(c) e^{-p t} d t
$$

$p>0$ - time preference rate. 
The market equilibrium in the presented model is determined based on the optimization problem maximizing the indicated utility function taking into account the limitation of knowledge accumulation and the production equation:

$$
U=\int_{0}^{\infty} u(c) e^{-p t} d t \rightarrow \max .
$$

Provided that $\dot{a} \geq 0$ and $a(0)$ is given, as well:

$$
U \dot{a}=a g\left(\frac{f(a, A)-c}{a}\right)
$$

As shown in the above equations - households, by giving up current consumption, contribute to investment growth. Consequently, this leads to the accumulation of knowledge in the economy, showing growing revenues and allowing faster production growth from a given size of savings.

The perfectly competitive economy in the Romer model is not optimal in the Pareto sense. Investments in knowledge made by one enterprise contribute to the increase in the general level of knowledge in the economy, which is a common factor of production. A single enterprise in its investment decisions does not include these positive externalities, which results in the fact that the marginal knowledge product from a single enterprise is smaller than the marginal knowledge product at the level of the entire economy.

This means that a perfectly competitive economy accumulates too little knowledge and shows a lower growth rate than the economy managed by a central planner. This conclusion is because the Romer model takes into account positive externalities. State intervention is therefore important from the perspective of the entire economy to ensure an adequate level of knowledge accumulation. Without state involvement, companies will only consider private costs and benefits. As a result, in a highly competitive economy, the level of knowledge and the rate of GDP growth will prove lower than in an economy with an active state.

\section{McMahon endogenous growth model}

An alternative to the Romer model presented is the model of endogenous growth proposed by McMahon(2018), which was based on the work of Lucas, covering with his interest the impact of science and technology on the formation of national income(Lucas, 2009; Lucas \& Moll, 2014).

where:

$$
Y_{t}=I_{t}\left(A K_{t}^{\beta}\left(\mu_{t} h_{t} N_{t}\right)^{1-\beta}\right) h_{a t}^{\gamma}
$$

$Y_{t}$ - goods and services measured in GDP;

$I_{t}$ - new ideas used to create and use available technology;

$A$ - level of technology that remains constant in the absence of new ideas;

$K_{t}$ - physical capital;

$\mu_{t}$ - share of hours that were not devoted to learning in the total available time (including working time);

$h_{t}$ - average human capital defined as knowledge (acquired during the training period) and other skills;

$N_{t}$ - population;

$h_{a t}$ - the average level of education. 
The key issue in the described model is to indicate the role of external factors, including public activities in shaping social values in the form of altruism or cultural development. Also, the importance of public education activities is underlined to support the humanities, which can contribute to improving the quality of life for future generations, while they are less popular compared to the private sector. This relationship is contained in the value $I_{t}$ representing the emergence of new ideas, as well as the share of time spent on learning $\left(1-\mu_{t}\right)$. This one would be much lower (especially in areas not directed at applied research) if the state did not play an intervention role.

The objective function aims to maximize the actual consumption per capita stream and in the case of this model is an indicator of optimal growth:

$$
\int_{0}^{\infty} \frac{1}{1-\sigma}\left(c_{t}^{1-\sigma}-1\right) e^{-p t} \delta t
$$

The consumption stream over an infinite time horizon $(t=0, \ldots, \infty)$ is discounted using the $p$ rate. The model also assumes the presence of consumer risk aversion marked by $\sigma$. Therefore, it is assumed that the state and individual households treat education (and the costs and benefits associated with it) in the long term. In turn, the value-added of human capital generated by households is given by the formula:

where:

$$
\frac{\delta h}{\delta t}=G_{t} / Y_{t} \delta\left(1-\mu_{t}\right) h_{t}
$$

$\frac{\delta h}{\delta t}$ - gross investment value in the creation of human capital;

$G_{t} / Y_{t}$ - is the part of the income allocated by the state to education (both public and private);

$\delta$ - accumulation factor assuming that $1-\mu_{t}=0$, and therefore all remaining time available is allocated by the unit to education.

In the model, only the activity of households and universities enables the implementation and application of innovative ideas. New technologies are created based on education, which also includes work (it can be employed in research units, enabling scientific development and other "creative" forms of work). The presented model assumes the creation of capital based on work in a given period, but also thanks to the ideas used during learning:

$$
\begin{gathered}
l_{t}=\alpha h_{t}^{\eta} \\
h_{t}=h_{t-1} \frac{\delta h}{\delta t}-d h_{t-1}
\end{gathered}
$$

Hence, human capital arises not only based on increasing the number of graduates of individual degrees of education but also during their professional work. The value of human capital in a given period can be aggregated by the sum of:

$$
H_{t}=\sum_{t=0}^{\infty} N_{t} I_{t} h_{t}
$$

The model, therefore, allows for taking into account the increase in human capital as an increase in the number of graduates and as the ability to spread knowledge after the end of the period of formal education.

The economic growth path defined as optimal, using the above assumptions, was presented in the model by the Hamiltonian equation: 


$$
\begin{aligned}
H\left(K, h, \theta_{1}, \theta_{2}, c, \mu, t\right) & =\frac{1}{1-\sigma}\left(c^{1-\sigma}-1\right)+\frac{\theta_{1}\left(I\left(A K^{\beta}(\mu h N)^{1-\beta}\right) h_{a}^{\gamma}-N c\right)}{N}+ \\
+ & \theta_{2}(G / Y \delta(1-\mu) h)
\end{aligned}
$$

This equation makes it possible to determine the optimal growth in consumption and income per capita, and also indicates the optimal path of development. Income is the sum of consumption, investment and government expenditure in a given period. In the model, the increase in income and consumption are equal, because the other variables are considered exogenous. Accordingly, the path of consumption growth can be determined based on:

$$
\left(\frac{\delta c}{\delta t}\right) c_{t}=M P P_{K t}-p
$$

This means that the optimal consumption growth rate is equal to the marginal efficiency of discounted physical capital. In a perfectly competitive economy, the marginal efficiency of discounted physical capital will be equal to the return on physical capital, which translates into a return on human capital:

$$
M P P_{K t}-p=M P P_{H t}-p=\left(\frac{\delta c}{\delta t}\right) c_{t}
$$

Based on the equation representing the optimal path of economic growth, it is also possible to determine a common rate of consumption, income and capital growth:

$$
\left(\frac{\delta c}{\delta t}\right) c_{t}=\frac{(1-\beta+\eta+\gamma)}{1-\beta}\left(\frac{\delta h}{\delta t}\right) h_{t}
$$

According to the model, the growth rate will be the higher the growth rate in investment in human capital will be. Also, along with the increase in external factors affecting education (e.g. new ideas or also an increase in government spending), this growth is accelerating. Hence, along with the increase in expenditure on the development of public education, the common growth rate of consumption, income and capital is accelerating. The same translation applies to social gratification resulting from the emergence of new skills. Along with the increase in education, there is an increase in the unit's wage to the entire population.

\section{MATERIAL AND METHODS}

\section{Statistical data and research method}

The study aimed to verify the determinants of GDP growth in Scandinavian countries with special regard to scientific progress. The research hypothesis was formulated as follows: scientific progress has an essential impact on the GDP growth in Scandinavian countries. Hypothesis verification process was carried out in the following way: the theoretical part represents the assumptions of Romers' learning-by-doing model and McMahons' model. Both models propose factors which explain economic growth, but their variables differ. Nonetheless, these are the two classical growth models that take into account scientific progress and human capital, unlike other models which focus on different types of determinants. By applying the multiple regression, all variables from the above models and other additional variables were combined, which made variable assessment possible, as to explain economic growth in the Scandinavian countries. The explanatory variables include selected data series related to key growth factors (such as: labour, human and physical capital) and additional ones determining scientific progress. The explained variable was GDP per capita (PPP based). The analytical software package Statistica was used to 
create the model. The data was downloaded from the World Bank (World Development Indicators), CEIC Data, ILOSTAT and International Monetary Fund databases. These databases provide access to the longest time series of variables allowing verification of the research hypothesis. The choice of the length of the tested series was dictated by their availability. For each of the analysed countries, the longest possible time series of variables was selected (for 1990-2016 with an annual frequency).

Table 1. List of indicators used in the analysis

\begin{tabular}{|c|c|c|}
\hline Type of variable & Indicator & Source \\
\hline $\begin{array}{l}\text { Dependent } \\
\text { variable }\end{array}$ & GDP per Capita: PPP & $\begin{array}{l}\text { World Bank (World Development In- } \\
\text { dicators) }\end{array}$ \\
\hline \multirow{13}{*}{$\begin{array}{l}\text { Independent } \\
\text { variable }\end{array}$} & $\begin{array}{l}\text { Adjusted Savings: Education Expendi- } \\
\text { ture }\end{array}$ & $\begin{array}{l}\text { World Bank (World Development In- } \\
\text { dicators) }\end{array}$ \\
\hline & Capital Stock: General Government & International Monetary Fund \\
\hline & Capital Stock: Private & International Monetary Fund \\
\hline & $\begin{array}{l}\text { Employment in Services: Modeled ILO } \\
\text { Estimate: \% of Total Employment }\end{array}$ & $\begin{array}{l}\text { World Bank (World Development In- } \\
\text { dicators) }\end{array}$ \\
\hline & $\begin{array}{l}\text { Expenditure: Net Investment in Nonfi- } \\
\text { nancial Assets }\end{array}$ & InternationalMonetary Fund \\
\hline & $\begin{array}{l}\text { Foreign Direct Investment: USD mn: } \\
\text { Annual }\end{array}$ & CEIC Data \\
\hline & $\begin{array}{l}\text { Gender Parity Index (GPI): Secondary } \\
\text { School Enrollment: Gross }\end{array}$ & $\begin{array}{l}\text { World Bank (World Development In- } \\
\text { dicators) }\end{array}$ \\
\hline & $\begin{array}{l}\text { Gender Parity Index (GPI): Tertiary } \\
\text { School Enrollment: Gross }\end{array}$ & $\begin{array}{l}\text { World Bank (World Development In- } \\
\text { dicators) }\end{array}$ \\
\hline & $\begin{array}{l}\text { Medium and High-Tech Exports: \% } \\
\text { Manufactured Exports }\end{array}$ & $\begin{array}{l}\text { World Bank (World Development In- } \\
\text { dicators) }\end{array}$ \\
\hline & Patent Applications: Non-Residents & $\begin{array}{l}\text { World Bank (World Development In- } \\
\text { dicators) }\end{array}$ \\
\hline & Patent Applications: Residents & $\begin{array}{l}\text { World Bank (World Development In- } \\
\text { dicators) }\end{array}$ \\
\hline & School Enrollment: Tertiary: \% Gross & $\begin{array}{l}\text { World Bank (World Development In- } \\
\text { dicators) }\end{array}$ \\
\hline & $\begin{array}{l}\text { Working time arrangement coverage: } \\
\text { Full-time and part time workers }\end{array}$ & ILOSTAT \\
\hline
\end{tabular}

Source: World Bank (World Development Indicators), International Monetary Fund, CEIC Data and ILOSTAT (access: 23.06.2020).

\section{RESULTS AND DISCUSSION}

The models were developed based on the above-mentioned independent variables. In addition to obtaining a high adjusted coefficient of determination $\left(\mathrm{R}_{\text {adjusted }}^{2}>0.95\right)$, the model had to meet the requirements of normal distribution using the Shapiro-Wilk test ( $p$ value $>0.05$ ). The results of the study for three selected countries are presented below.

Figure 1. shows the GDP per capita trend model explained by values representing scientific development in Sweden. The adjusted coefficient of determination takes the value of 0.9965 , which indicates a very good fit of the model to the values observed in reality. 
The Shapiro-Wilk test of normality (SW $-\mathrm{W}=0.9714 ; \mathrm{p}=0.7441$ ) showed that the model meets the requirements of normal distribution. The following equation of the model explains the evolution of GDP per capita in Sweden:

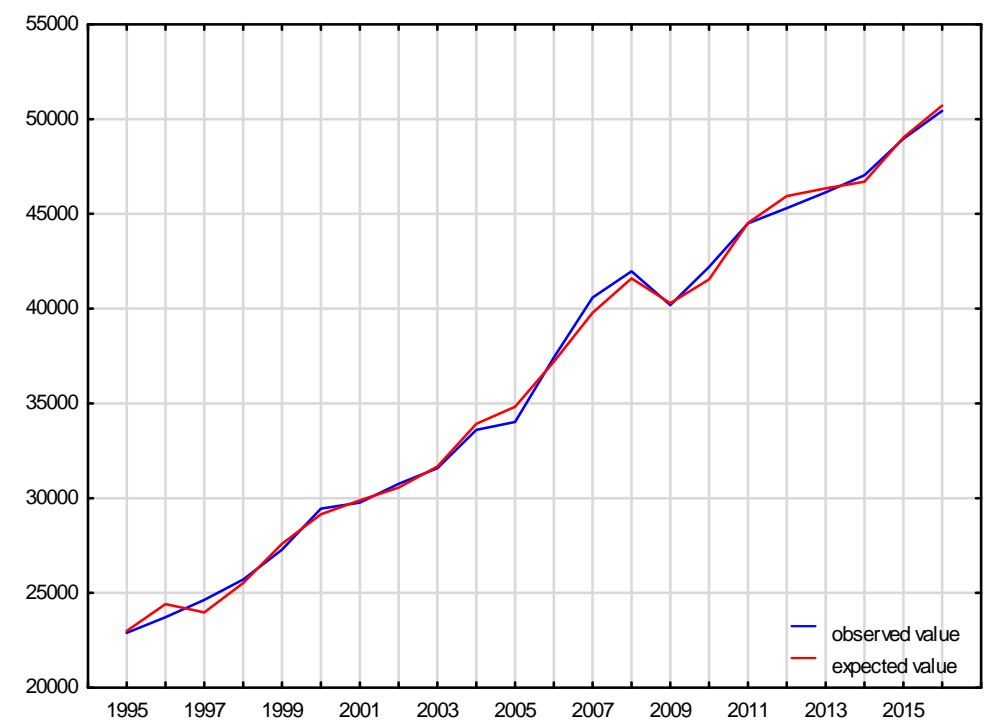

Figure 1. Expected regression model values relative to observed GDP per capita (adjusted by purchasing power parity) in Swedenin 1995-2016 period Source: own calculations based on data from the World Bank (World Development Indicators), International Monetary Fund, CEIC Data and ILOSTAT(access: 23.06.2020).

$$
\begin{gathered}
Y_{S}=-68176.9+36.987 * x_{1}-6.4761 * x_{2}+582.216 * x_{3}+9.238 * x_{4}- \\
-75.713 * x_{5}-12427.9275 * x_{6}+1.5983 * x_{7}
\end{gathered}
$$

where:

$Y_{S}$ - model regression function for Sweden;

$x_{1}$ - Capital Stock: General Government;

$x_{2}$ - Capital Stock: Private;

$x_{3}$ - Medium and High-Tech Exports: \% Manufactured Exports;

$x_{4}$ - Working time arrangement coverage: Full-time and part time workers;

$x_{5}$ - School Enrollment: Tertiary: \% Gross;

$x_{6}$ - Gender Parity Index (GPI): Secondary School Enrollment: Gross;

$x_{7}$ - Patent Applications: Residents.

The study shows that the change in GDP per capita in Sweden is affected by:

- positively: Capital Stock: General Government; Medium and High-Tech Exports; Working time arrangement coverage: Full-time and part time workers; Patent Applications: Residents;

- negatively: Capital Stock: Private; School Enrollment: Tertiary: \% Gross; Gender Parity Index (GPI): Secondary School Enrollment: Gross. 


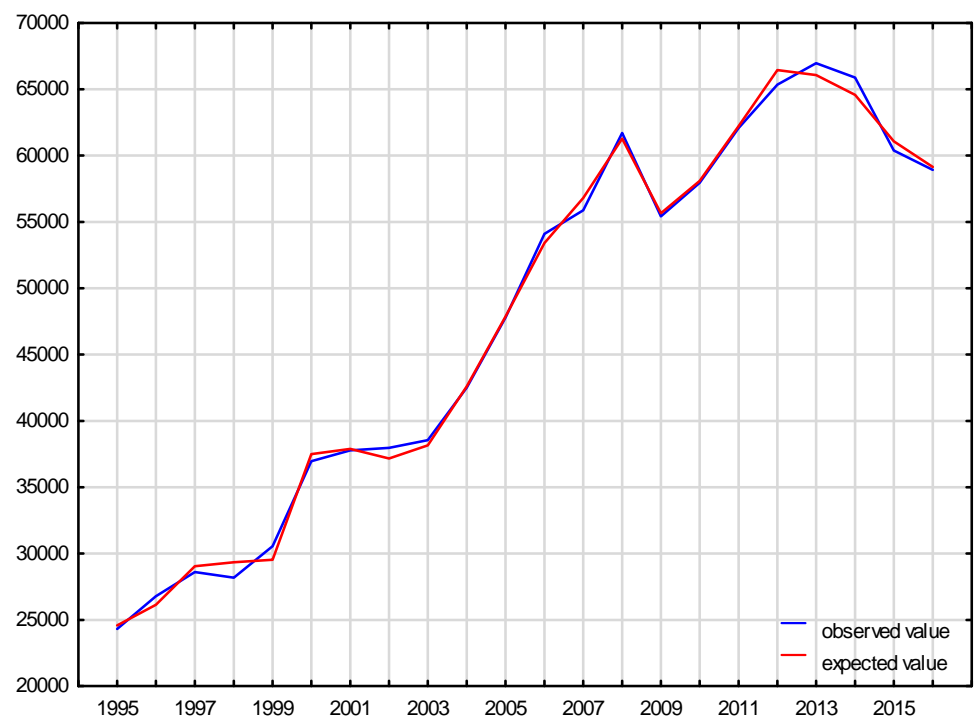

Figure 2. Expected regression model values relative to observed GDP per capita (adjusted by purchasing power parity) in Norwayin 1995-2016 period

Source: own calculations based on data from the World Bank (World Development Indicators), International Monetary Fund, CEIC Data and ILOSTAT(access: 23.06.2020).

The adjusted coefficient of determination in Norway reached 0.9963 , which indicates a very good fit of the model. There were also no grounds for rejecting the hypothesis of normal distribution (Shapiro-Wilk test: $\mathrm{SW}-\mathrm{W}=0.9603 ; \mathrm{p}=0.4961$ ). The model equation took the following form:

$$
\begin{gathered}
Y_{N}=-191638.49+3272.3457 * x_{1}-670.8313 * x_{2}+38.6884 * x_{3}- \\
-43.8548 * x_{4}-66748.2877 * x_{5}+2.0461 * x_{6}-16.653 * x_{7}
\end{gathered}
$$

where:

$Y_{N}$ - model regression function for Norway;

$x_{1}$ - Employment in Services: Modeled ILO Estimate: \% of Total Employment;

$x_{2}$ - Medium and High-Tech Exports: \% Manufactured Exports;

$x_{3}$ - Working time arrangement coverage: Full-time and part time workers;

$x_{4}$ - Capital Stock: General Government;

$x_{5}$ - Gender Parity Index (GPI): Secondary School Enrollment: Gross;

$x_{6}$ - Patent Applications: Non-Residents;

$x_{7}$ - Capital Stock: Private.

The variables that turned out to be significant for this model are:

- positively related: Employment in Services: Modeled ILO Estimate: \% of Total Employment; Working time arrangement coverage: Full-time and part time workers; Patent Applications: Non-Residents; 
- negatively related: Medium and High-Tech Exports: \% Manufactured Exports; Capital Stock: General Government; Gender Parity Index (GPI): Secondary School Enrollment: Gross; Capital Stock: Private.

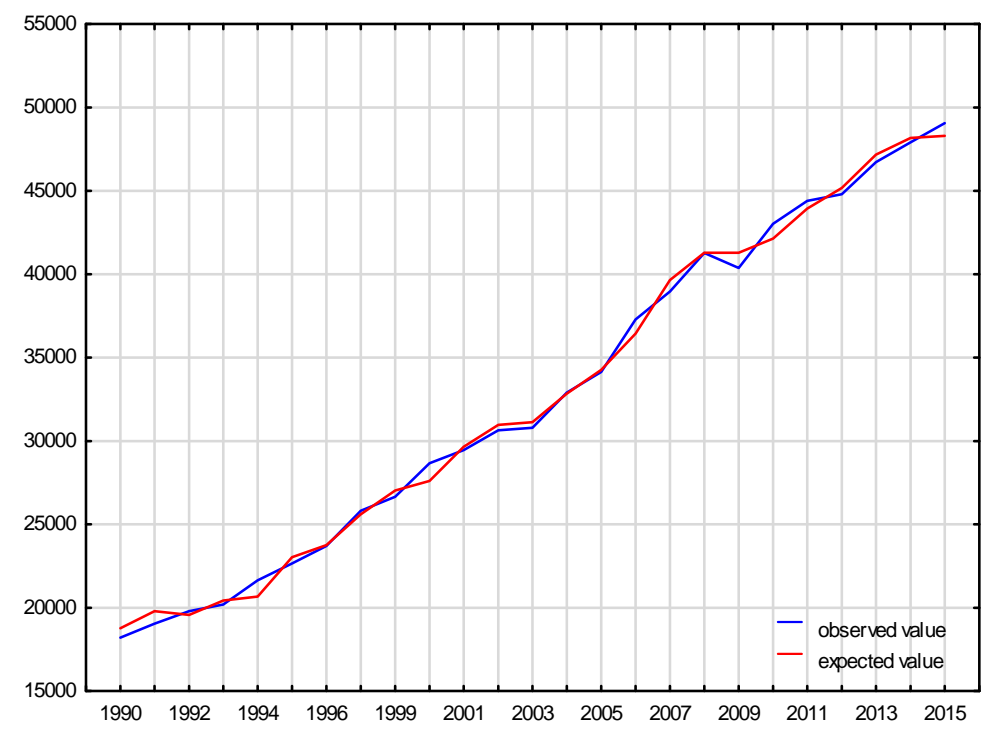

Figure 3. Expected regression model values relative to observed GDP per capita

(adjusted by purchasing power parity) in Denmark in 1990-2015 period

Source: own calculations based on data from the World Bank (World Development Indicators), International Monetary Fund, CEIC Data and ILOSTAT(access: 23.06.2020).

The model showing the GDP per capita of Denmark using the variables determining the development of science reached the value of the adjusted coefficient of determination 0.9963 . The high coefficient was shaped by variables that are components of the following equation:

$$
\begin{gathered}
Y_{D}=-23104.5016+38.0182 * x_{1}+0.1951 * x_{2}-9296.1249 * x_{3}+ \\
+315.9805 * x_{4}+0.1841 * x_{5}
\end{gathered}
$$

where:

$Y_{D}$ - model regression function for Denmark;

$x_{1}$ - Capital Stock: General Government;

$x_{2}$ - Expenditure: Net Investment in Nonfinancial Assets;

$x_{3}$ - Gender Parity Index (GPI): Tertiary School Enrollment: Gross;

$x_{4}$ - Medium and High-Tech Exports: \% Manufactured Exports;

$x_{5}$ - Adjusted Savings: Education Expenditure.

After the Shapiro-Wilk test ( $\mathrm{SW}-\mathrm{W}=0.9224 ; \mathrm{p}=0.0582$ ), there were no grounds for rejecting the normal distribution hypothesis. The model shows that the following variables have the greatest impact on shaping GDP per capita in Denmark:

- negatively: Gender Parity Index (GPI): Tertiary School Enrollment: Gross; 
- positively: Capital Stock: General Government; Expenditure: Net Investment in Nonfinancial Assets; Medium and High-Tech Exports: \% Manufactured Exports; Adjusted Savings: Education Expenditure.

\section{CONCLUSIONS}

It can be stated that the determinants of the classical economic growth models proposed by Romer and McMahon, which include expenditures of other factors of production (capital, labour, etc.) and the emergence of new ideas (e.g. patent applications), had an impact in explaining the increase of GDP per capita in Scandinavian countries. However, not only that: the additionally proposed indicators defining scientific progress, e.g. growth of net investment in non-financial assets in Denmark, as well as medium and high-tech exports as \% of manufactured exports in Sweden and Denmark (in case of Norway, this variable has had an opposite effect) also had a significant impact on the dependent variable. The presented relationships, the theoretical introduction of economic growth models, literature query and empirical verification has allowed to formulate the most important conclusions:

- Both in Sweden and Denmark, the medium and high-tech exports as\% of manufactured exports has the largest impact on GDP per capita growth. In Norway, on the other hand, employment in service as\% of total employment has the largest positive impact on GDP per capita growth. This shows the high dependence of the service sector and the export of modern technologies in the context of economic growth in these countries.

- Each country has different factors determining economic growth. However, the variable that repeated in each model is negatively affecting the Gender Parity Index (in Sweden and Norway in secondary and in Denmark in tertiary education).

- For this group of countries as a whole, it cannot be determined whether the size of capital stock (both general government and private) has a positive or negative impact. The case of each country should be considered separately.

As a whole, the study provides current confirmation of theoretical models of economic growth for highly developed countries, where education and human capital are very important in the context of their development. Additionally, thanks to the conducted empirical analysis the proposed hypothesis that: scientific progress has an essential impact on the GDP growth in Scandinavian countries, was confirmed. A similar verification may be used in the future for medium-developed and developing countries to check the impact of this category of variables on GDP per capita.

\section{REFERENCES}

Aghion, P., \& Howitt, P. (Eds.) (1998). Endogenous growth theory. MIT Press.

Becker, G.S. (1993).Human capital: A theoretical and empirical analysis, with special reference to education / Gary S. Becker (3rd ed.). The University of Chicago Press.

Benhabib, J., \& Spiegel, M.M. (1994). The role of human capital in economic development evidence from aggregate cross-country data.Journal of Monetary Economics, 34(2), 143-173. https://doi.org/10.1016/0304-3932(94)90047-7

Chlebisz, A., Gruszowski, P., \& Igielski, K. (2019). Edukacja i szkolnictwo a rozwój gospodarczy w Polsce na tle wybranych krajów europejskich w latach 2005-2017.Rynek-Społeczeństwo-Kultura,1, 54-58. 
Diamond, P.A. (1965). National Debt in a Neoclassical Growth Model.The American Economic Review, 55(5), 1126-1150. Retrieved from www.jstor.org/stable/1809231

Florczak, W. (2009). Koncepcja wzrostu endogenicznego i gospodarki opartej na wiedzy wnaukach ekonomicznych.Studia Prawno-Ekonomiczne, 80, 215-239.

Galor, O., \& Tsiddon, D. (1997). The Distribution of Human Capital and Economic Growth.Journal of Economic Growth, 2(1), 93-124. https://doi.org/10.1023/A:1009785714248

Garncarz, J., \& Mierzejewski, M. (2019). The Impact of Crises on the Intellectual Capital of Companies in the Food Sector.E-Finanse, 15(3), 1-9. https://doi.org/10.2478/fiqf-2019-0015

Hanushek, E.A., \& Woessmann, L. (2020). Education, knowledge capital, and economic growth. In S. Bradley \& C. Green (Eds.), The Economics of Education (pp. 171-182). Elsevier. https://doi.org/10.1016/B978-0-12-815391-8.00014-8

Krueger, A., \& Lindahl, M. (1999).Education for Growth in Sweden and the World. Cambridge, MA. https://doi.org/10.3386/w7190

Krueger, A.B., \& Lindahl, M. (2001). Education for Growth: Why and For Whom?Journal of Economic Literature, 39(4), 1101-1136. Retrieved from www.jstor.org/stable/2698521

Lucas, R.E. (1988). On the mechanics of economic development.Journal of Monetary Economics, 22(1), 3-42. https://doi.org/10.1016/0304-3932(88)90168-7

Lucas, R.E. (2009). Ideas and Growth.Economica, 76(301), 1-19. https://doi.org/10.1111/j.14680335.2008.00748.x

Lucas, R.E., \& Moll, B. (2014). Knowledge Growth and the Allocation of Time.Journal of Political Economy, 122(1), 1-51. https://doi.org/10.1086/674363

Mankiw, N. G., Romer, D., \& Weil, D. (1992). A Contribution to the Empirics of Economic Growth.The Quarterly Journal of Economics, 107(2), 407-437. Retrieved from https://EconPapers.repec.org/RePEc:oup:qjecon:v:107:y:1992:i:2:p:407-437.

Mas, M., Hofman, A., \& Benage, E. (1998). Economic valuation of knowledge-based capital: An international comparison. In P. Aghion \& P. Howitt (Eds.), Endogenous growth theory. MIT Press.

McMahon, W.W. (2018). The total return to higher education: Is there underinvestment for economic growth and development?The Quarterly Review of Economics and Finance, 70, 90-111. https://doi.org/10.1016/j.qref.2018.05.005

Mincer, J. (1984). Human capital and economic growth.Economics of Education Review, 3(3), 195205. https://doi.org/10.1016/0272-7757(84)90032-3

Nelson, R.R., \& Phelps, E. S. (1966). Investment in Humans, Technological Diffusion, and Economic Growth.The American Economic Review, 56(1/2), 69-75. Retrieved from www.jstor.org/stable/1821269

North, D.C. (2010). Understanding the process of economic change. The Princeton economic history of the western world. Princeton University Press.

OECD (2020).Education at a Glance 2020: OECD. https://doi.org/10.1787/19991487

Pelinescu, E. (2015). The Impact of Human Capital on Economic Growth.Procedia Economics and Finance, 22, 184-190. https://doi.org/10.1016/S2212-5671(15)00258-0

Ramsey, F.P. (1928). A Mathematical Theory of Saving.The Economic Journal, 38(152), 543. https://doi.org/10.2307/2224098

Rebelo, S. (1991). Long-Run Policy Analysis and Long-Run Growth.Journal of Political Economy, 99(3), 500-521. https://doi.org/10.1086/261764

Romer, P. (1986). Increasing Returns and Long-Run Growth.Journal of Political Economy, 94(5), 10021037. https://doi.org/10.1086/261420 
Romer, P. (1990a). Endogenous Technological Change.Journal of Political Economy, 98(5), S71-102. Retrieved from https://EconPapers.repec.org/RePEc:ucp:jpolec:v:98:y:1990:i:5:p:s71-102

Romer, P. (1990b). Human capital and growth: Theory and evidence.Carnegie-Rochester Conference Series on Public Policy, 32, 251-286. https://doi.org/10.1016/0167-2231(90)90028-J

Sala-i-Martin X., Doppelhofer, G., \& Miller, R.I. (2004). Determinants of Long-Term Growth: A Bayesian Averaging of Classical Estimates (BACE) Approach. The American Economic Review, 94(4), 813-835. Retrieved from www.jstor.org/stable/3592794

Sato, R. (1964). The Harrod-Domar Model vs the Neo-Classical Growth Model.The Economic Journal, 74(294), 380. https://doi.org/10.2307/2228485

Silfvenius, P.K. (2014).Innovation and economic growth in Norway. University of Stavanger, Norway.

Solow, R.M. (1956). A Contribution to the Theory of Economic Growth.The Quarterly Journal of Economics, 7O(1), 65. https://doi.org/10.2307/1884513

Topel, R. (1999). Labor markets and economic growth. In O. Ashenfelter \& D. Card (Eds.),Handbook of Labor Economics (pp. 2943-2984). Elsevier. Retrieved from https://EconPapers.repec.org/RePEc:eee:labchp:3-44

Wang, Z. (2019). Economic Growth. In Z. Wang (Ed.), The principle of trading economics (pp. 463507). Springer.

Wilson, R., \& Briscoe, G. (2004). The impact of human capital on economic growth: a review. In P. Descy \& M. Tessaring (Eds.), Impact of education and training: Third report on vocational training research in Europe: background report (pp.13-61). Cedefop Reference series, No. 54. Office for Official Publications of the European Communities. 


\section{Authors}

The contribution of co-authors is as follows: Adam Chlebisz prepared the literature review, data collection, statistical calculations and data analysis (51\%), Mateusz Mierzejewski - literature review, theory development and data analysis (49\%).

\section{Adam Chlebisz}

Student of economics at Cracow University of Economics. His research interests include financial markets, economic and social changes in developing countries as well as economic crises.

Correspondence to: e-mail: adam.chlebisz@gmail.com

\section{Mateusz Mierzejewski}

PhD student at Cracow University of Economics. His research interests include macroeconomic research focuses on analysing the phenomena of the relationship between economic growth and improving the quality of social life. He applies an interdisciplinary approach to the phenomena studied, using the achievements of other fields of science, in particular philosophy and sociology. Correspondence to: Mgr Mateusz Mierzejewski, Cracow University of Economics, College of Economics, Finance and Law, Department of Organizational Development, ul. Rakowicka 27, 31-510 Kraków, Poland, e-mail: mateusz.mierzejewski@uek.krakow.pl

ORCID (1) http://orcid.org/0000-0001-8542-2373

\section{Copyright and License}

This article is published under the terms of the Creative Commons

Attribution - NoDerivs (CC BY-ND 4.0) License http://creativecommons.org/licenses/by-nd/4.0/

Published by Cracow University of Economics - Krakow, Poland

The journal is co-financed in the years $2019-2020$ by the Ministry of Science and Higher Education of the Republic of Poland in the framework of ministerial programme "Support for Scientific Journals" (WCN) on the basis of contract no. 238/WCN/2019/1 concluded on 15 August 2019. 
